\title{
Analysis of Urban Air Pollution and The Effectiveness of Air Pollution Control Policy in Malaysia: Case Study in Klang Valley, Malaysia*
}

\author{
Siti Haslina Mohd Shafie, ${ }^{\text {T Suzani Mohamad, }}{ }^{2}$ Nor Lita Fadilah Rameli, ${ }^{3}$ \\ Sahala Benny Pasaribu ${ }^{4}$ \\ ${ }^{1}$ Centre for Research in Development, Social and Environment, \\ Faculty of Social Sciences and Humanities, Universiti Kebangsaan Malaysia \\ ${ }^{2}$ Department of Environment, Faculty of Forestry and Environment, \\ Universiti Putra Malaysia, ${ }^{3}$ Institute for Environment and Development, \\ Universiti Kebangsaan Malaysia, ${ }^{4}$ Faculty of Economics and Business, \\ Universitas Trilogi
}

\begin{abstract}
Air pollution in Malaysia is largely attributed to motor vehicles and land transportation, industrial activities and open burning. It has a hazardous effect on the public's health and the environment. This study focuses on the spatial analysis of carbon monoxide (CO) and ozone $\left(\mathrm{O}_{3}\right)$ concentrations trend in Klang Valley stations, specifically in Klang, Petaling Jaya, Kajang, Shah Alam and Cheras from 2000 to 2009. The study used the Inverse Distance Weighted (IDW) interpolation technique under the Geographic Information System (GIS). This study found that the distribution pattern of $\mathrm{CO}$ spatial concentrations in the Klang Valley is the highest concentration and reached $2.5 \mathrm{ppm}$, especially in Klang and Petaling Jaya stations in 2002 and 2003. However, the annual concentration of $\mathrm{O}_{3}$ recorded in Klang, Petaling Jaya, Kajang, Shah Alam, and Cheras stations from 2004 to 2009 is between 0.01 to $0.025 \mathrm{ppm}$. While air quality legislations have been introduced in Malaysia, policies and regulations being established by the government, their enforcement is still weak. Subsequently, air pollution is still a significant issue in Malaysia. Strong cooperation between the government, stakeholders and the local community is important to promote environmental sustainability and improve the community's well-being.

Keywords: Air pollution; Geographic Information System (GIS); Air Quality Policy; Malaysia
\end{abstract}

\footnotetext{
* Received: December 12, 2020, revised: January 16, 2021, accepted: February 12, 2021, Published: April 1, 2020.

1 Siti Haslina Mohd Shafie is a PhD in Geography Programme, Centre for Research in Development, Social and Environment, Faculty of Social Sciences and Humanities, Universiti Kebangsaan Malaysia. ORCID: https://orcid.org/0000-0002-3093-9567.

2 Suzani Mohamad is a PhD Candidate in Department of Environment, Faculty of Forestry and Environment, Universiti Putra Malaysia.

${ }^{3}$ Nor Lita Fadilah Rameli is a PhD Candidate in Environment and Development, Institute for Environment and Development, University Kebangsaan Malaysia

${ }^{4}$ Sahala Benny Pasaribu is a $\mathrm{PhD}$ in Economic Development in Faculty of Economics and Business, Universitas Trilogi

Corresponding author: sitihaslina87@gmail.com
} 
Siti Haslina Mohd Shafie, Suzani Mohamad, Nor Lita Fadilah Rameli, Sahala Benny Pasaribu

\author{
Analisis Polusi Udara Perkotaan dan Efektivitas Kebijakan Pengendalian Polusi \\ Udara di Malaysia: Studi Kasus di Lembah Klang, Malaysia
}

\begin{abstract}
Abstrak
Polusi udara di Malaysia sebagian besar disebabkan oleh kendaraan bermotor dan transportasi darat, kegiatan industri dan pembakaran terbuka. Ini memiliki efek berbahaya pada kesehatan publik dan lingkungan. Penelitian ini berfokus pada analisis spasial trend konsentrasi karbon monoksida (CO) dan ozon (O3) di stasiun Klang Valley, tepatnya di Klang, Petaling Jaya, Kajang, Shah Alam dan Cheras dari tahun 2000 sampai 2009. Penelitian menggunakan Inverse Distance Weighted (IDW) teknik interpolasi di bawah Sistem Informasi Geografis (SIG). Penelitian ini menemukan bahwa pola sebaran konsentrasi spasial CO di Lembah Klang merupakan konsentrasi tertinggi dan mencapai 2,5 ppm terutama di stasiun Klang dan Petaling Jaya pada tahun 2002 dan 2003. Namun demikian, konsentrasi $\mathrm{O} 3$ tahunan tercatat di Klang, Petaling Jaya, Stasiun Kajang, Shah Alam, dan Cheras dari 2004 hingga 2009 berkisar antara 0,01 hingga 0,025 ppm. Meskipun undang-undang kualitas udara telah diperkenalkan di Malaysia, kebijakan dan peraturan ditetapkan oleh pemerintah, penegakannya masih lemah. Selanjutnya polusi udara masih menjadi masalah yang signifikan di Malaysia. Kerja sama yang kuat antara pemerintah, pemangku kepentingan, dan masyarakat lokal penting untuk mendorong kelestarian lingkungan dan meningkatkan kesejahteraan masyarakat.
\end{abstract}

Kata Kunci: Polusi udara; Sistem Informasi Geografis (SIG); Kebijakan Kualitas Udara;

Malaysia

Анализ загрязнения воздуха в городах и эффективности политики контроля за загрязнением воздуха в Малайзии: тематическое исследование в Лембах Кланг, Малайзия

\begin{abstract}
Аннотация
Загрязнение воздуха в Малайзии в значительной степени связано с автотранспортом и наземным транспортом, промышленной деятельностью и открытым сжиганием. Это опасно для здоровья населения и окружающей среды. В этом исследовании основное внимание уделяется пространственному анализу тенденции концентраций окиси углерода (CO) и озона $\left(\mathrm{O}_{3}\right)$ на станции Klang Valley, особенно в Кланге, Петалинг-Джая, Каджанге, Шах-Аламе и Черасе с 2000 по 2009 г. Данное исследование

применяет

Сглаживание с Весом обратно Пропорциональным Расстоянию $\quad$ (IDW), метода интерполяции в Географической Информационной Системе (ГИС). Это исследование показало, что характер распределения пространственных концентраций СО в Лембах Кланг является наивысшим и достигал 2,5 частей на миллион (2,5рpm), особенно на станциях Кланг и Петалинг-Джая в 2002 и 2003 годах. Однако годовая концентрация $\mathrm{O}_{3}$, зарегистрированная на станциях Кланг, Петалинг-Джая, Каджанг, Шах-Алам и Черас с 2004 по 2009 год, составляет от 0,01 до 0,025 частей на миллион (2,5рpm). Несмотря на то, что в Малайзии были приняты законы 0 качестве воздуха, политика и постановления устанавливаются правительством, их соблюдение все еще остается слабым. Следовательно, загрязнение воздуха по-прежнему остается серьезной проблемой в Малайзии. Тесное сотрудничество между правительством, заинтересованными сторонами и местным сообществом важно для обеспечения экологической устойчивости и улучшения благосостояния сообщества.

Ключевые слова: Загрязнение воздуха; Географическая Информационная Система (ГИС); Политика качества воздуха; Малайзия
\end{abstract}




\section{A. INTRODUCTION}

Malaysia is one of the developing countries in the world that experiencing a serious urban air pollution problem. Various causative factors, such as population growth and rapid economic activity, has contributed to rapid urbanization. This situation is evident in the city centre, resulting in a drastic change to the environment that brings health hazards to the local community.

According to the Department of Environment (DOE), mobile sources, specifically, motor vehicles are the dominant contributors to pollution between 1998 and 2014, compared to stationary sources such as industrial activities, power generation and other sources. Concerning the pollutants emitted by motor vehicles was found that they emit 1,996,256 metric tonnes of carbon monoxide (CO); 449,895 metric tonnes of hydrocarbons (HC); 224,096 metric tonnes of nitrogen dioxide $\left(\mathrm{NO}_{2}\right) ; 14,514$ metric tonnes of sulfur dioxide $\left(\mathrm{SO}_{2}\right)$ and 4,121 metric tonnes suspended particulate matter less than 10 micrometres (PM10) in 2017 (DOE 2017, p. 112). This situation creates a serious air pollution problem, especially in urban areas. People in these areas are exposed to high levels of pollutants and significantly bringing harmful effects to their health.

Previous studies in Malaysia have concluded that urban air pollution is significantly harmful to an individual's health, as we inhale pollutants as we breathe (Mabahwi et al., 2014, p. 6; Ling et al., 2010, p. 510 \& 2012, p. 180). According to the World Health Organization (WHO), complications caused by air pollution accounted for 7.6 per cent of all deaths in all cases worldwide in 2016 (WHO 2016, p. 1-18). This condition is influenced by individual exposure to pollutant concentrations and short- and long-term continuous exposure to pollutants. The Ministry of Health $(\mathrm{MOH})$ also confirmed that respiratory diseases are one of the main causes of hospital admission with 10.35 percent and the leading cause of deaths with 19.48 percent in 2011 (MOH, 2012, p. 5).

Therefore, this study is conducted to analyze Malaysia's urban air pollution by focusing on the Klang Valley, which has the country's fastest urbanization rate. The analysis of urban air pollution in the Klang Valley is done based on the spatial distribution of $\mathrm{CO}$ and $\mathrm{O}_{3}$ pollutants recorded in selected study stations, Klang, Petaling Jaya, Kajang, Shah Alam, and Cheras on the long-time trend of 10 years (from 2000 to 2009). This study will also identify and determine the areas with the most significant amount of $\mathrm{CO}$ and $\mathrm{O}_{3}$ pollutants by year, and the most hazardous area for the local community. Furthermore, the mitigation and implementation measures introduced and practised by the government to control and reduce the negative impact of urban 
air pollution on the environment and the local community is examined in the context of their effectiveness. The mitigation and implementation measures introduced encompass government agencies' role and function in establishing acts and policies to make the environment clean and safe for the people in Malaysia in general, and specifically in Klang Valley.

\section{Study Location}

The Klang Valley is the most developed urban area in Malaysia, and it is mostly situated in Selangor. In this study, data were recorded from five air quality stations, namely Klang, Shah Alam, Petaling Jaya, Kajang and Cheras stations located in the districts of Klang, Petaling, Hulu Langat and the Federal Territory of Kuala Lumpur (Table 1).

Table 1 DOE Air quality monitoring station in Klang Valley

\begin{tabular}{llll}
\hline Area ID & $\begin{array}{l}\text { DOE Air quality monitoring } \\
\text { station }\end{array}$ & Longitude & Latitude \\
\hline CAC 011 & SM (P) Raja Zarina, Klang & $10124.484^{\prime} \mathrm{E}$ & $30.620^{\prime} \mathrm{N}$ \\
CAC 016 & SK Sri Petaling, Petaling & $10142.274^{\prime} \mathrm{E}$ & $36.612^{\prime} \mathrm{N}$ \\
& Jaya & & \\
CAC 023 & Country Heights, Kajang & $10144.417^{\prime} \mathrm{E}$ & $259.645^{\prime} \mathrm{N}$ \\
CAC 025 & Sekolah TTDI Jaya, Shah & $10133.368^{\prime} \mathrm{E}$ & $36.278^{\prime} \mathrm{N}$ \\
& Alam & & \\
CAC 054 & SMK Seri Permaisuri, & $10143.072^{\prime} \mathrm{E}$ & $36.376^{\prime} \mathrm{N}$ \\
& Cheras & & \\
\hline
\end{tabular}

Source: Department of Environment 2010

The Klang Valley has various types of local land use due to the robust human activities in the area. There are seven main types of land use classes identified in five major cities in the Klang Valley based on the Intergovernmental Panel classes for Climate Change (IPCC). These land-use classes include housing and municipal land use, agriculture, forests, grasslands, mangrove swamps and other land uses. These land-use classes have been set the IPCC are varied according to the area's size and location (Figure 1).

In terms of population, the Malaysian Population and Housing Census 2010 published by the Department of Statistics Malaysia reported that the Klang 
Valley's total population is $5,334,589$. In 2010 , most of the population $(30 \%$ or 1588,750 people) live within the Kuala Lumpur City Hall administrative district. The DBKL area is also the main residential area with 468,325 residential units in 2010. The increase in the number of residential areas is directly influenced by the increase in population and the rapid urbanization of areas within KL.

\section{B. METHODS}

\section{Materials: Data source}

This study's main data source is the concentration of criterion pollutants, namely $\mathrm{CO}$ and $\mathrm{O}_{3}$, obtained from DOE, for Klang, Petaling Jaya, Kajang and Shah Alam stations for a period of 10 years from 2000 to 2009. Meanwhile, only the data from 2004 to 2009 were obtained from Cheras station. To ensure the measurement process's reliability, the equipment used was subjected to regular monitoring and calibration by Alam Sekitar Sdn. Bhd. (ASMA), a private company mandated by the DOE.

\section{Method: Data Analysis using Geographical Information System (GIS)}

This study focuses on applying spatial data analysis techniques based on interpolation via Geographic Information Systems (GIS). GIS is an information system capable of storing, retrieving, managing, processing, analyzing and re-displaying non-spatial (non-spatial) data, and spatial data for problem-solving and decision-making purposes. The GIS software consists of ArcGis, ArcInfo, ArcView or MapInfo, which could store and analyze data more systematically. In the meantime, spatial analysis is the process of manipulating spatial information to form and produce new information from the original data source on the phenomenon being studied.

The interpolation technique refers to a set of procedures applied to predict new cells' value in areas with limited sampling points. This depends on the main principle of spatial analysis: the degree or level of dependence and the relationship between sampling points located near or far from each other. Therefore, the Inverse Distance Weighted (IDW) interpolation technique was applied in the study. In this regard, the variable or point mapped in an area is influenced by its distance from the sampling location, where the sampling point located far from the sampling location will have a weak and reduced weightage. Thus, sampling points located close to each other will have the same characteristics and properties. 


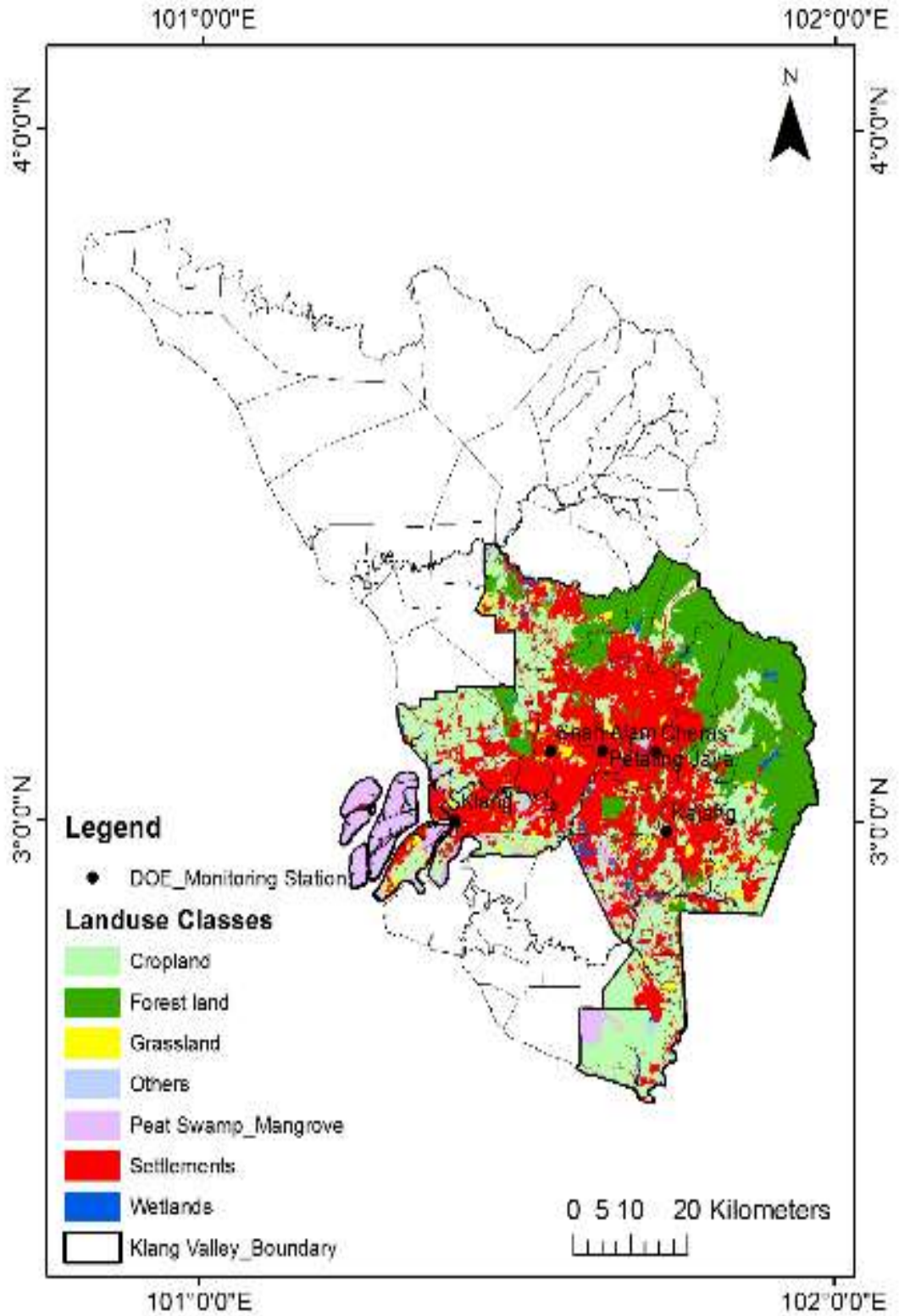

Figure 1 Landuse, cover change and locations of DOE monitoring station sites in the Klang Valley, 2011

Source: Selangor Department of Agriculture 2011 
Table 2 Land use and cover change in Klang Valley

\begin{tabular}{lcc}
\hline No. & Land use and cover change & Area (hectare) \\
\hline 1. & Cropland & 3330.95 \\
2. & Forest land & 1688.94 \\
3. & Settlements & 1489.76 \\
4. & Peat swamp mangrove & 1168.8 \\
5. & Grassland & 235.32 \\
6. & Wetlands & 127.66 \\
7. & Others & 109 \\
\hline
\end{tabular}

Source: Selangor Department of Agriculture 2011

The IDW is formulated as:

$$
z(x)=\frac{\sum_{i=1}^{n} w_{i}(x) z_{i}}{\sum_{j=1}^{n} w_{j}(x)}, w_{i}(x)=\frac{1}{d\left(x, x_{i}\right)^{p}}
$$

Where:

$\mathrm{Z}(\mathrm{x})=$ predicted value at the interpolated point; $x_{i}=$ value of the $i$-th known sample point, i.e. the annual average concentration of $\mathrm{CO}$ and $\mathrm{O}_{3}$ at five air quality stations; $d=$ distance between the known sample point and the prediction point; $n=$ total number of the known sample point refers to five air quality stations namely Klang, Petaling Jaya, Kajang, Shah Alam and Cheras; $w_{i}$ $=$ weight assigned to $i$-th known sample point and $p=$ weighting power, and commonly, this value is considered as 2 .

\section{RESULT AND DISCUSSION}

\section{The annual distribution pattern of $\mathrm{CO}$ spatial concentrations in five Klang Valley air quality stations from 2000 to 2009}

The annual distribution pattern of $\mathrm{CO}$ spatial concentrations in five Klang Valley air quality stations, namely Klang, Petaling Jaya, Kajang, Shah Alam and Cheras, showed a decline from 2000 to 2009 (Figure 2). This situation is evident in the Klang and Petaling Jaya stations, the main stations with the highest annual CO concentrations at 2 to 2.5 ppm in 2002 and 2003. Petaling 
Jaya stations also recorded CO concentrations of between 1.5 to $2 \mathrm{ppm}$, especially in 2003 to 2006, compared to other station like Shah Alam in 2002.

In the meantime, the Klang station recorded the minimum $\mathrm{CO}$ concentration in 2000 and 2001. This concentration decreased from 2003 to 2009 to between 0.5 to $1.5 \mathrm{ppm}$. The same situation is recorded in the Petaling Jaya station which recorded a low CO concentration of between zero to $0.5 \mathrm{ppm}$ between 2000 to 2002. This increased to around 1.5 to $2.5 \mathrm{ppm}$ from 2003 to 2009. A similar trend was observed in Shah Alam station, which recorded low $\mathrm{CO}$ concentrations of 0.5 to $1 \mathrm{ppm}$ in 2000 and 2001 before increasing to 1 to 1.5 ppm between 2004 to 2007. The concentration further decreased to between 0.5 to $1 \mathrm{ppm}$ in 2008 and 2009.

The CO concentration distribution trend in Kajang station showed a uniform pattern of between zero to $1 \mathrm{ppm}$ per year, except in 2002 where the $\mathrm{CO}$ concentrations were recorded at between 1 to $1.5 \mathrm{ppm}$. Meanwhile, the data from Cheras station recorded the annual $\mathrm{CO}$ concentrations in the range of zero to $1 \mathrm{ppm}$, compared to between 2004 and 2006 with a concentration level of between 1 to $1.5 \mathrm{ppm}$. The data showed an increasing CO concentration pattern in the Klang Valley from 2002 to 2006 before decreasing in 2009.

\section{The annual distribution pattern of $\mathrm{O}_{3}$ spatial concentrations in five Klang Valley air quality station from 2000 to 2009}

The annual concentration of $\mathrm{O}_{3}$ in the Klang Valley showed an increasing pattern based on the spatial scale in Klang, Petaling Jaya, Kajang, Shah Alam and Cheras air quality stations from 2000 to 2009 (Figure 3). The increasing trend of $\mathrm{O}_{3}$ concentration was observed from 2004 to 2009, where the concentration in Shah Alam and Kajang stations are in the range between 0.01 to $0.025 \mathrm{ppm}$. In this light, the Shah Alam, Kajang and Cheras stations recorded the highest concentrations in 2004 and 2005at 0.02 to $0.025 \mathrm{ppm}$.

Shah Alam and Kajang stations recorded the annual $\mathrm{O}_{3}$ concentrations of between 0.015 and 0.025 ppm 2000 to 2003. Klang stations also recorded high $\mathrm{O}_{3}$ concentrations of between 0.01 and 0.02 annually. The Klang station was identified as the station with the highest $\mathrm{O}_{3}$ concentrations in 2009 at approximately $0.025 \mathrm{ppm}$. Regarding the Petaling Jaya station, it was found that the $\mathrm{O}_{3}$ concentration trend is between 0.01 to $0.02 \mathrm{ppm}$ from 2003 to 2009. Based on the annual $\mathrm{O}_{3}$ concentration space distribution at the Klang Valley air quality stations, it can be concluded that the Klang, Petaling Jaya, Kajang, Shah Alam 
and Cheras stations have recorded significantly averages ranging from 0.01 to 0.025 ppm from 2004 to 2009.

\section{Enforcement of Air Quality Legislation and Policies in Malaysia}

Based on the need to protect the environment and to create a balance in the nation's development, several environmental legislations have been introduced to regulate and control air pollution in Malaysia (Mustafa \& Mohd. Rusli 2016, p. 156). The Environmental Quality Act 1974 (Act 127) was gazetted on 14 March 1974. It came into force on 15 April 1975 to prevent, eliminate, control pollutants, preserve the environment and support other environmental initiatives (Environmental Quality Act, 1974, p. 5). The Malaysian government has been stern in addressing environmental issues with economic development, as discussed in the 6th Malaysia Plan, to achieve sustainable development (Mustafa 2011, p. 8).

Table 3 Legislation, Acts and Regulations on Environmental Quality (Clean Air) Act 1974 (Act 127)

No. $\quad$ Acts, Rules, Regulations \& Orders

The effective

date of

Enforcement

1 Environmental Quality (Clean Air) Regulations $1978 \quad 1^{\text {st }}$ October 1978

2 Environmental Quality (Clean Air) Regulations $2014 \quad$ 4 $4^{\text {th }}$ June 2014

3 Environmental Quality (Control of Petrol and Diesel $11^{\text {st }}$ April 2007 Properties) Regulation 2007

4 Environmental Quality (Control of Emission from $1^{\text {st } J a n u a r y ~} 2004$ Motorcycles) Regulation 2003

5 Environmental Quality (Control of Emission from $1^{\text {st }}$ November Petrol Engines) Regulation $1996 \quad 1996$

6 Environmental Quality (Control of Emission from $1^{\text {st }}$ September Diesel Engines) Regulation 19961996

$7 \quad$ Environmental Quality (Control of Lead Concentration $\quad 1^{\text {th }}$ July 1987 in Motor Gasoline) Regulation 1985

8 Environmental Quality (Declared Activity) (Open 1st January 2004 


\begin{tabular}{|c|c|c|c|}
\hline & Burning) Order 2003 & & \\
\hline 9 & $\begin{array}{l}\text { Environmental Quality (Delegation of } \\
\text { (Investigation of Open Burning) Order } 2000\end{array}$ & Powers) & $\begin{array}{l}\qquad 1^{\text {st }} \\
\text { August } 2000\end{array}$ \\
\hline 10 & $\begin{array}{l}\text { Environmental Quality (Compounding of } \\
\text { (Open Burning) Rules } 2000\end{array}$ & Offences) & $\begin{array}{l}21^{\text {st }} \text { August } \\
2000\end{array}$ \\
\hline 11 & $\begin{array}{l}\text { Environmental Quality (Compounding of } \\
\text { Rules } 1978\end{array}$ & Offences) & $1^{\text {st }}$ October 1978 \\
\hline
\end{tabular}

Source: Environmental Quality (Clean Air) Act 1974

The Environmental Quality Act 1974 (Act 127) outlines several legislation, regulations and approaches to addressing air pollution, as shown in Table 3. This reflects the government is committed and proactive in addressing air pollution issues through improving several action plans and policies. These include the National Policy on the Environment, Malaysia Environmental Strategic Plan 2011-2020 (UNEP, 2015, p. 1), National Haze Action Plan 1997, Open Burning Prevention Plan 2015, Clean Air Action Plan 2011 and ASEAN policy on Zero Burning in Palm Oil Planting 1999 (Kamaruddin et al. 2017, p. 172-174). The legislation, policies and action plans developed are statements of the Malaysian government's endless efforts to control and reduce the impact of air pollution on the environment and the community, especially in terms of protecting public health.

\section{The Effectiveness of Air Pollution Policy}

a. Motor vehicles and land transportation

Despite the environmental laws enforced in Malaysia, the question remains on the effectiveness of environmental law enforcement as air pollution remains a pertinent issue in Malaysia. Shafie \& Mahmud (2020), p. 2,793) reported that motor vehicles and traffic are the dominant causes of urban air pollution in Malaysia. This situation is also supported by Chin et al. (2019), p. 15) that reported that while 65 percent of the study sample are aware of health hazards of air pollutants from vehicles, they rejected the idea of using public transportation. This is because society still negatively perceives the public transportation system's efficiency and accessibility (Bazrbachi et al., 2017, p. 77 $\& 79)$. 
Since the implementation of Outlined Perspective Plan 3 (OPP3), the Malaysian government has taken various systematic measures to overcome air pollution issues from various sources. One of the significant measures is increasing enforcement of pollutant emissions from motor vehicles and implementing a comprehensive traffic management system (Maragatham \& Rafaj, 2013, p. 3). Focus is given to cutting down PM10 emissions by all motor vehicle classes, which were recorded at 1,029,883 $\mathrm{kg}$ in Kuala Lumpur from 2010 to 2014.

In terms of vehicle class, the highest PM10 emission in 2014 was recorded by private vehicles with $214,427 \mathrm{~kg}$, compared to motorcycles at $118,582 \mathrm{~kg}$. Private vehicles also recorded a high CO and NOx production at $14,605 \mathrm{~kg}$ and 5,726 kg, respectively, in 2014 (Shafie \& Mahmud, 2020, p. 2,796).

The government has enforced the Environmental Quality (Emissions Control From Diesel Engine) Regulations 1996 and the Environmental Quality (Emissions Control From Petrol Engine) Regulations 1996 under the supervision of DOE. Besides, the control of excess black smoke emissions from the exhaust of diesel vehicles is monitored through the AWASI Program (Area Watch and Sanction Inspection). The 2,253 enforcement activities were implemented in several cities across the country throughout 2016 and overall, the percentage of diesel vehicles' compliance is 99.35 percent, a decrease of 0.35 percent compared to 2015 (DOE, 2016, p. 80).

The government has also implemented the CO and HC Gas Emissions Control Initiative. Throughout 2016, a total of 1,889 petrol-powered vehicles on the road were tested for $\mathrm{CO}$ and $\mathrm{HC}$ emissions using $\mathrm{CO}-\mathrm{HC}$ Analyzer gas meters through the "idling" test method. 50 vehicles were compounded for failing to comply with the emission limits. The overall compliance percentage is $98.25 \%$, an increase of $0.25 \%$ percent compared to 2015 (DOE, 2016, p. 81).

In line with the implementation of the European Economic Commission on Standards or EURO standards, Maragatham \& Rafaj (2013, p. 4) argued that the improvement of fuel quality by oil companies in Malaysia should be in line with the EURO 2 standard for diesel and petrol. According to these new standards, diesel's sulfur content should be significantly reduced from 3,000 ppm to 500 ppm and from 1,500 to 500 ppm in petrol. Subsequently, diesel and petrol in the Malaysian market were upgraded to EURO 3 standards in 2014. 


\section{Open burning}

The ban on open burning was enacted in the Environmental Quality (Clean Air) Regulations 1978. It is aimed to prevent open burning activities which contributed to haze problems in the local area. According to the DOE, 543 hectares of open burning hot spots were identified in Sepang and Kuala Selangor, Selangor. Furthermore, open burning for agricultural activities has caused an unhealthy Air Pollution Index in Klang Valley between February and March 2002 (Mahmud, 2005, p. 33; Rahman et al., 2015, p. 5). Another pertinent issue is the cross-border haze crisis that hit several countries in Southeast Asia, including Malaysia, resulting from the slash-and-burn farming methods to clear forests and peatland for agricultural activity across Kalimantan and Sumatra, Indonesia (Cheong et al., 2019, p. 2). The ASEAN Agreement on Transboundary Haze Pollution (AATHP) was signed in June 2002 in Kuala Lumpur by ASEAN countries-Malaysia, Singapore, Indonesia, Thailand, Vietnam, Brunei, Laos, Philippines, Cambodia and Myanmar. It is aimed to control, prevent and reduce the impact of cross-border haze and came into force in 2003 (Kamaruddin et al., 2017, p. 178; Ku Yusof et al., 2017, p. 750). The AATHP Agreement has adopted international customary laws such as Principle 21 of the Stockholm Declaration (1972), Principle 2 of the Rio Declaration (1992), Responsibility of States for Internationally Wrongful Acts (2001) and Prevention of Transboundary Harm from Hazardous Activities (2001) (Ku Yusof et al., 2017, p. 750). Malaysia has implemented various legal measures to control, prevent and resolve the air pollution issue in the country. However, despite the efforts to control the different sources of pollutants, the set targets are yet to be achieved due to the government's weak enforcement, stakeholders, and lack of cooperation from local communities.

\section{CONCLUSIONS}

The deterioration of air quality in Malaysia is attributed to several sources of pollutants, motor vehicles, industrial activities, power generation activities, and open burning. It was observed that the $\mathrm{CO}$ spatial concentration distributions in the Klang Valley had decreased from 2000 to 2009 with the highest concentration of $2.5 \mathrm{ppm}$. Klang and Petaling Jaya stations were identified as the main stations with high annual CO concentrations of between 2 to 2.5 ppm in 2002 and 2003 compared to Kajang, Shah Alam and Cheras stations. However, the annual concentrations of $\mathrm{O}_{3}$ in the Klang Valley showed an increasing pattern based on the spatial scale in the Klang Valley between 2000 and 2009. This situation is evidenced by the increasing trend of $\mathrm{O}_{3}$ 
concentrations of between 0.01 to 0.025 ppm from 2004 to 2009 in Klang, Petaling Jaya, Kajang, Shah Alam and Cheras station. Therefore, the Malaysian government have introduced several legislations, acts, policies and regulations to reduce, control and overcome the negative impact of air pollution on the environment and the local community. However, the effectiveness of these legislations, policies, and regulation remains a major question to the government and the local community. This is because air pollution is still significant in Malaysia, especially in the Klang Valley due to weak enforcement. This situation shows the need for more stringent implementation and enforcement by government agencies. Furthermore, strong, proactive and integrated cooperation between government agencies, stakeholders and the local community is important towards environmental sustainability and social well-being.

\section{REFERENCES:}

Bazrbachi, A., Sidique, S.F., Shamsudin, M.N., Radam, A., Kaffashi, S. \& Adam, S.U. (2017). Willingness to pay to improve air quality: A study of private vehicle owners in Klang Valley, Malaysia. Journal of Cleaner Production. 148:73-83. https://doi.org/10.1016/j.jclepro.2017.01.035

Cheong, K.H., Ngiam, N.J., Morgan, G.G., Pek, P.P., Tan, B.Y.Q., Lai, J.W., Koh, J.M., Ong, M.E.H., Ho, AFW. (2019). Acute health impacts of the Southeast Asian transboundary haze problem - A review. International Journal of Environmental Research and Public Health 16(18): 3286: 1-18. DOI: 10.3390/ijerph16183286.

Chin, Y.S.J, De Pretto, L., Thuppil, V. \& Ashfold, M.J. (2019). Public awareness and support for environmental protection $-A$ focus on air pollution in Peninsular Malaysia. PLoS ONE 14(3):e0212206. DOI: 10.1371/journal.pone.0212206

Department of Environment (DOE). (2010). Malaysia Environmental Quality Report 2010. Department of Environment, Putrajaya, Malaysia

Department of Environment (DOE). (2016). Annual Report 2017. Department of Environment, Putrajaya, Malaysia

Department of Environment (DOE). (2017). Malaysia Environmental Quality Report 2017. Department of Environment, Putrajaya, Malaysia 
Environmental Quality Act 1974 (Act 127). Environmental Quality (Clean Air) Regulations 1978. PU (A) 280/78, Federal Subsidiary Legislation 1978. Percetakan National Malaysia Berhad, Lawnet.

Kamaruddin, H., Ahmad, R.A \& Mohammad Shapien, R. (2017). Transboundary haze pollution: legislation and enforcement in Malaysia and Singapore. Kanun: Jurnal Undang-undang Malaysia 29(1): 160-197. ISSN 2682-8057. Retrieved from http://jurnal.dbp.my/index.php/Kanun/article/view/1154

Ku Yusof, K.M.K., Azid, A., Samsudin, M.S. \& Jamalani, M.A. (2017). An overview of transboundary haze studies: The underlying causes and regional disputes on Southeast Asia region. Malaysian Journal of Fundamental and Applied Sciences 13 (4): 747-753. DOI: 10.11113/mjfas.v0n0.719

Laws of Malaysia. (1974). Environmental Quality Act 194 (Act 127). Federal Subsidiary Legislation, Percetakan National Berhad, Lawnet.

Ling, H.L.O., Ting, K.H., Ahmad, S., Aiyub, K. \& Mohd Jani, Y. (2010). Air quality and human health in urban settlement: Case study of Kuala Lumpur city. The 2010 International Conference on Science and Social Research (CSSR 2010): 510-515. DOI: 10.1109/CSSR.2010.5773831

Ling, O.H.L., Ahmad, S., Aiyub, K., Mohd Jani, Y. (2012). Urban air environmental health indicators for Kuala Lumpur City. Sains Malaysiana 41: 179-191. Retrieved from http://www.ukm.my/jsm/pdf files/SM-PDF41-2-2012/05\%20Oliver.pdf

Mabahwi, N.A.B., Leh, O.L.H. \& Omar, D. (2014). Human health and well-being: Human health effect of air pollution. Procedia - Social and Behavioral Sciences 153: 221-229. https://doi.org/10.1016/j.sbspro.2014.10.056

Mahmud, M. (2005). Active fire and hotspot emissions in Peninsular Malaysia during the 2002 burning season. Geografia-Malaysian Journal of Society and Space 1: 32-45. ISSN 2180-2491. Retrieved from https://ejournal.ukm.my/gmjss/article/view/17780/5509

Maragatham, K. \& Rafaj, P. (2013). Assessment of Air Pollution and GHG Mitigation Strategies in Malaysia using the GAINS Model. NTC 2013: Nuclear Technical Convention 2013, Malaysia. Retrieved from https://inis.iaea.org/search/search.aspx?orig q=reportnumber:\%22INISMY--2014-022\%22 
MOH. (2012). Health Facts 2012. Ministry of Health Malaysia: Health Informatics Center. Ministry of Health Malaysia, Putrajaya, Malaysia.

Mustafa, M. (2011). The Environmental Quality Act 1974: The Environmental Quality Act 1974: A significant legal instrument for implementing environmental policy directives of Malaysia. IIUM Law Journal 19(1): 1-34. DOI: $\underline{10.31436 / \text { iiumlj.v19i1.1 }}$

Mustafa, M. \& Mohd. Rusli, M.H. (2016). The position of environmental law in Malaysia in dealing with domestic and regional air pollution problems. Jurnal Sultan Alauddin Sulaiman Shah 3(2) : 155-165. ISSN: 2286-8042. Retrieved from http://journal.kuis.edu.my/jsass/images/files5/jsass vol3bil2 012 MAIZA TUN.pdf

Rahman, S.R.A., Ismail, S.N.S., Raml, M.F., Latif, M.T., Abidin, EZ \& Praveena, S.M. (2015). The assessment of ambient air pollution trend in Klang Valley, Malaysia. World Environment. 5: 1-11. DOI: 10.5923/j.env.20150501.01

Selangor Department of Agriculture. (2011). Annual Report Selangor Department of Agriculture 2011. Selangor Department of Agriculture, Shah Alam, Malaysia

Shafie, S.H.M \& Mahmud, M. (2020). Urban air pollutant from motor vehicle emissions in Kuala Lumpur, Malaysia. Aerosol and Air Quality Research. 20: 2793-2804. https://doi.org/10.4209/aaqr.2020.02.0074.

United Nation Environment Programme. (2015). Air Quality Policies in Malaysia. UN Environment Programme. Retrieved from https://www.unenvironment.org/resources/policy-and-strategy/airquality-policies-malaysia

WHO. (2016). World Health Statistics 2016: Monitoring health for the SDGs. World Health Organization. Retrieved from https://www.who.int/gho/publications/world health statistics/2016/Ann ex B/en/. Geneva: World Health Organization. 
Siti Haslina Mohd Shafie, Suzani Mohamad, Nor Lita Fadilah Rameli, Sahala Benny Pasaribu

28 - JURNAL CITA HUKUM (Indonesian Law Journal). Vol. 9 Number 1 (2021). P-ISSN: 2356-1440.E-ISSN: 2502-230X 